\title{
The Pragmatic Functions of 'Mashi' in Modern Arabic Language
}

\author{
Hamid I. Al-Shishtawi \\ Amman- Jordan
}

\begin{abstract}
The discourse marker 'mashi', literally means 'walking', has gained a variety of pragmatic (i.e. contextual) meanings over time; and has become one of the most common discourse markers in daily interactions among Arabs. Data has been collected from the website Arabicorpus where more than 400 instances of the DM 'mashi' were found. The study enumerates 28 different functions of the DM 'mashi' depending on its contextual realizations: threatening, approval, walking, end the speech, etc. The sample of the study consists of all 65 English language Ph.D students in two divisions in The University of Jordan, 47 questionnaires data were tested. The results indicated that the use of the word Mashi was understood to $87.9 \%$ by the sample of the study.
\end{abstract}

Keywords: Contextual meaning, discourse marker"mashi", Modern spoken Arabic, corpus

\section{Introduction}

This study is an examination of the use of the Discourse Marker "Mashi" in Modern Arabic language (Henceforth DM). DM is a linguistic type that is mostly utilized in oral conversations to connect speech units to each other (e.g. well, but, still, oh, hmm, okay, and, however, I mean, you know, so, etc.). It is a significant element that shares the coherence of the spoken discourse and plays a main role in its interpretation. It is also significant in explaining the communication intentions of the interlocutors. DM can be localized, and relate to contiguous units immediately to talk to each other or to the world. According to Piurko (2015) despite the role of DM in the production of texts, it is believed that the signs of speech are empty and grammatically optional. However, instead of seeing those as one of the easiest and most meaningful, speech signs meet a variety of pragmatic functions at the scriptural level and interpersonal relationships. It is claimed that speech marks, which refer to different types of boundaries, help to alter the spoken speech or mark a loop in written speech, perform textual tasks.

Language contains an invaluable treasure of linguistic and social terms that serve many functions and purposes, regardless of its type and family. These terms are often spoken rather than written, which explains why they are often ignored. Marmorstein (2016) stated that among linguists concerned with the natural structure and dynamics of language, DM remains a constant concern. Although it can generally be dispensed with to construct well-formed sentences, the signs of discourse are virtually indispensable for producing any stretch of unscheduled natural discourse, thus providing a salient expression of its structural distinction. However, DM is not only a means of promoting coherent speech, but also indicators that teach the listener mental processes and interactive movements performed by the speaker. The analysis of DM therefore provides a promising way to unravel the workings of natural discourse at a number of interrelated sentences.

"Mashi" is also pragmatic and problematic in nature and seems to serve as a unit of language with a wide scope of context-dependent references. As it will be exemplified in different contexts, this marker draws attention and focus on the proposition being conveyed within and across sentence boundaries. It covers more or less the functions and meanings of well, agree, right, end, ok, so, no problem, anyhow and good and so on. The word "Mashi" is defined as a common Arabic word, used in many Arab countries including Egypt, Jordan and Saudi Arabia, and has many meanings such as, ok, good, and moving. So, Shabi (2016) explained common Arabic word as the dialect spoken in the present era of the standard spoken in the era of spontaneous eloquence and dialects, and suffered many changes after the mixing of Arabs with others, such as the fall of the expressions in all cases and others, because the daily communication is subject to error other than the language of writing, Speech expression. The subject of this article is the (DM) "Mashi" in Arabic, which is used specifically in operative discourse. The word "Mashi" is a lexicon that has several meanings according to its position within the context. It is also considered to be very frequent in spontaneous conversation in many Arabic dialects. 


\subsection{Objectives of study}

The purpose of the study is to identify the use of the word Mashi according to Arabi corpus, and to know the extent of knowledge of Arabic students from non-Arabs of those uses, the aim of the study is to formulate in clearing out The pragmatic functions of 'mashi' in Modern Arabic Language.

\subsection{Defining of Discourse Marker}

There are many definitions of Discourse Marker according to many researchers, where Fraser (1999) showed that the term Discourse Marker has various meanings for various researchers, and he find work on Discourse Markers done according to many of labels involving (discourse connectives, discourse operators, discourse particles, discourse signaling devices, phatic connectives, pragmatic connectives, pragmatic expressions, pragmatic formatives, pragmatic markers, pragmatic operators, pragmatic particles, semantic conjuncts, sentence connectives). Jucker (1993) indicated that occasionally the term 'discourse particle' is utilized mutually with the term 'discourse marker'. E.g. utilizes the former term to indicate to same linguistic elements for which utilizes the latter. Occasionally the two terms are utilized to refer to varied phenomena. DMs also defined as "sequentially dependent elements which bracket units of talk, where it combines interactional and variation approaches to discourse to analyze the roles of markers in co-constructed discourse" (Alami 2015: 2). Schiffrin (2005) showed that Discourse markers expressions (such as well, but and oh) are one collection of linguistic Elements that work in expressive, textual, cognitive and social fields. Hutchinson (2004) defined DMs as "lexical items (possibly multiword) that signal relations between propositions, events or speech acts".

\subsection{Language Competence and performance}

A native speaker of Specific language has the automatic ability to recognize the practical function of the word when applied in different contexts. This ability is part of the native speaker's knowledge of the language. The Cuurent study exmines the (DM) "Mashi". In this study, identifying Discourse Marker "Mashi" relied on the Arabic competance of language especially when "Mashi" is used in different context. A native speaker of specific language has also the ability to produce utterances in many contexts, where this ability is considered as performance. Competence and performance are known as part of the basic generative grammar. Competence considered as the basic knowledge of language. Also, it is concerned with comprehension performance is relevant to the speak (spoken or written) (Brown, Malmkjær and Williams 1996).

Language Competence is defined as a broad term which involves linguistic or grammatical competence, discourse competence, sociolinguistic or socio-cultural competence, and what might be called textual competence. The specific learning outcomes under the heading Language Competence deal with knowledge of the language and the ability to use that knowledge to interpret and produce meaningful texts appropriate to the situation in which they are used. Language competence is best developed in the context of learning activities or tasks where the language is used for real purposes, in other words, in practical applications (Littlemore and Low 2006). Competance is also the rules that a user has mastered, so that it may be possible for that user to produce and understand an infinite number of sentences. Moreover, competence enables the speaker to recognize mysterious sentences; it lets accepting apparently meaningless speakes as syntactically correct and making some sence. For examble, an English speaker can differentiate if the sentence is incorrect or not even if not used before. A native speaker has the knowledge of the words used in his language, whetger in formal interactions or in informal ones (Chomisky 1986).

A native speaker has the knowledge to use expressions in many contexts to achieve communication. Pragmatic expressions are part of the original competence of the speaker. Pragmatic expression may seem aesthetically free among a speaker who has language competence. Competance defined by Lyons (1995) as knowledge in a particular language, by those who have knowledge are able to produce and understand the terms regarding to this language. Djigunovic (2007) showed that Communication competence is consist of two words, which are meant to combine efficiency on communication. Djigunovic (2007) suggested that communicative competence involved two words, whose combination mean competence to communicate.

Whatever, to communicate successfully in the target language, the pragmatic competence in the second language must be well developed. Language competence is difficult for the second language learner, where communicative competence has many categories, such as linguistic competence and pragmatic competence. Chomsky (1981) defined pragmatic competence as the ability to put language in international settings to use, to link intentions and objectives with linguistic means at hand. The adoption of pragmatic competence as a second language learning goal does not necessarily mean that pragmatism requires any special attention in the teaching of language. Pragmatical knowledge develops simply along with lexical and grammatical knowledge, without the need for any educational intervention (Rueda 2006). 
So, it is important that the native speaker utilizes difficult words and expressions for non-native speakers to understand. Pragmatic competence is a specific concept, which includes language competence and communication competence as well as an idea of how to build the context and what participants require. Participants, status, age, status and other features are part of the communication context (De Aquino 2011).

\section{Theoretical background}

The linguists were concerned with the discourse markers (DMs). They dealt with many topics that had a value in the linguistic structure within the discourse. The markers formed an important starting point for researchers in the literary texts and their linguistic fabric on the significance of the linguistic and non-linguistic marker (Farouk 2018). A study of Fraser (1999) aimed to clarify the status of discourse markers. The study was based on research, literary reviews and previous studies. Lexical expressions have been studied under various labels, including discourse markers, discourse connectives, discourse operators, pragmatic connectives, sentence connectives, and cue phrases. After reviewing prior theoretical research, Study defined discourse markers as a class of lexical expressions drawn primarily from the syntactic classes of conjunctions, adverbs, and prepositional phrases.

Feng (2010) pointed out that DMs terms are one group of linguistic items that work in discourses of many methods. He also indicated that DM taught in a diversity of languages and examined in many of kinds and reactive contexts since the late 1980's, though various researchers do not concur on how to define them. Ariel (2009) showed that discourse and grammar are two totally different aspects of persons' communication. Grammar considered as a many of languagespecific symbols, usually limited to units at the sentence level. It directs speakers on how to construct sentences correctly, which are then assembled through a completely different set of principles (discourse) in a coherent discourse. Discourse is the output of the utilize grammar in certain natural contexts. It usually includes a many of words (most sentences) that are organized in a non-random way. Discourse is a pattern of markers related to groups, persons, or even subjects. Each format of the discourse has controversial features distinguish it from other patterns, and these features are determined by the experts of discourse or rather specialist in the discourse analysis (Fagari 2013).

DM defined as "sequentially dependent elements that bracket units of talk, i.e. non-obligatory initial items that function in relation to ongoing talk and text" (Piurko 2015: 16). It is also "cue phrases are linguistic expressions — such as okay, but, now, anyway, by the way, in any case, that reminds me - which may, instead of making a 'semantic' contribution to an utterance (i.e., affecting its truth conditions), be used to convey explicit information about the structure of a discourse" (Kawamo, Himazu and Awabata 1996).Ms are generally referred to as "connecting words," "connecting phrases," or "sentence connectors". Can be described as "glue" that binds part of the writing, making different parts of the text "stick together" (Chuang 2017).

Vickov and Jakupčević (2017) investigated the use of discourse markers in nonnative (Croatian) EFL teachers' talk with primary and secondary school students. The study concentrated on the occurrences and frequencies of discourse markers, but it also provided an account of the function distribution of the three most frequently used discourse markers (ok, so, and). The quantitative and qualitative analyses of the recorded transcriptions revealed that the teachers used a variety of discourse marker, almost exclusively the ones typical of classroom management and classroom discourse organization, with no significant differences in the patterns of discourse marker use with the primary and secondary school students. The discourse markers fulfill a number of structural and interpersonal functions mainly aimed at providing coherent and stimulating classroom discourse. Study recommended that raising awareness of the diversified functions of discourse markers, which could facilitate non-native EFL teachers' overall lesson organization and structuring of particular teaching segments.

\section{Literature review}

There are many studies related to discourse marker or pragmatic function that helps the current study, Al-Ghoweri (2016) aimed to shed some light on the use and pragmatic functions of 'alzalakom 'allah"' (may God elevate you) in Modern Arabic language. Study was carried out on Jordanian native speakers of Modern Arabic language. Study sample consisted of (13) individuals of both genders (male and female), and different age groups (young, middle-aged, and old). Study asked the participants when and why they use "alalakom'allah" (God elevate you) in daily interactions. Study showed that "alzalakom 'allah" (God elevate you) is used in Modern Arabic language for certain functions. It also showed the usage of "alzalakom'allah'(God elevate you) in Modern Arabic language is associated with animals, impure Places, reprehensible situations. It is used to express indirect politeness since animals, impure Places, reprehensible situations are considered to be taboos in Jordanian culture. Marmorstein (2016) explored the range of the use of the discourse marker yaSni (lit. "it means") in a corpus of interviews with Cairene women in Egypt. The analysis of yaSni carried out within a framework, which aimed to capture both the cognitive processes and the communicative goals which yasni facilitates and cues. 
Study showed that yaSni is a marker whose core function is to signal the speaker's cognitive efforts to get to her point, that is, to produce the most satisfying expression of her intended message, relative to the local or global topic of discourse. Al Rousan (2015) examined the use of the discourse marker 'Ma3 Nafsak' in Saudi Spoken Arabic. The study explored the pragmatic function of 'Ma3 Nafsak' in the online conversation of young studies. Study sample consisted of 17 young Saudi students through user-diaries, consisted of 262 natural online conversations in which 132 cases of 'Ma3 Nafsak' occurred.

Data were analyzed with regard to the pragmatic functions of the discourse marker. Study showed that 'Ma3 Nafsak' serves 12 different pragmatic functions based on the context in which it is used. Study also emphasized the significant of the context in the interpretation of discourse markers. Study recommended that Conduct further research on this study.Mehawesh and Jaradat (2015) assumed that the expression 'inshallah' has various non-literal meanings besides the literal one which is an invocation to Allah to enable the speaker to achieve a positive or a negative action. The nonliteral meanings, on the other hand, are all cases of flouting Grice's maxim of quality, whereby the speaker does not mean what the words literally mean; however, the addressee or the hearer can figure out the message intended by the speaker. Study found out that the various non-literal meanings 'inshallah' serves are: irony, which a typical means for flouting the maxim of quality, threatening, wonder, yes/ok, prohibition, and wishing. Moreover, the study showed that the utterances containing the expression 'inshallah' will not give the same meaning after the removal of 'inshallah'.

Alami (2015) indicated that in his study a review of related literature for pragmatic functions of discourse markers. Study relied on reviewing the theoretical approaches towards discourse markers that ushered in the past three decades. Study provided the reader with the knowledge about how DMs operate at textual and interpersonal levels of discourse, where the implementation of the study were for those who interested in DMs and their functions in making conversation smooth. Study showed that studies on spoken language in real-life contexts increased dramatically. As a result, some of the features previously considered "emptye" "superfluous "e and redundant- such as sort of, " $y$ know" and well, now are considered as crucial aspects of interpersonal communication. These expressions called "discourse markers" or "pragmatic expressions" have been of "substantial interest to researchers studying situated language use because of their role in demarcating discourse connections as well as their potential for indexing social relationships".

Alazzawie (2014) indicated to lexical item 'yamawwad', which is the functional discourse unit with several different functions that are dependent upon context, where study showed that its function difficult to define since it varies with context but, at the same time, it is a topic of great interest in the study of discourse, pragmatics and speech acts. The material used in study came from dyadic conversations that were written and transcribed. The range of contexts where 'yamawwad' occurs were identified and then classified into sections according to the various contextual meanings and functions of this pragmatic marker.

Kanakri and Al-Harahsheh (2013) explored the discourse functions of the discourse marker "Pa:di" in Modern Arabic language. The data analyzed consisted of 20 video-taped dyadic conversations in Jordanian Arabic. These conversations were transliterated and then translated into English. Discourse analysis is employed as a theoretical framework for the current study. Study showed that the adjective "?a:di" has many discourse functions, its pragmatic meaning relies on the context of situation and its translatability is cultural specific. Study recommended that the present study motivates many scholars to tackle many similar linguistic issues and phenomena in Arabic. Study of Hellermann and Vergun (2007) aimed to investigate the classroom interaction and in-home, bilingual interviews. Study sample consisted of 17 adult learners of English with no previous formal English language instruction in order to find the frequency of use and some functions of forms of language, which not explicitly taught: the discourse markers well, and like. Previous findings in this area are based most often on data from more advanced language learners and do not present a clear picture of which learners use these markers more often or why. Study showed that this set of learners used few discourse markers. A review of the focal students' background information (including language use patterns outside the classroom) suggested that the students who use more discourse markers might be the students who more acculturated to the US. This suggested that the students who comprise the population at the data collection site, in general, remain, to some degree, isolated from English language culture in the US.

\section{Methodology}

The present study follows quantitative method of research. The data were collected using questionnaires carried out on the study sample which involves (28) selected texts from http://arabicorpus.byu.edu/search.php, then transliterated into Arabic, and then they were translated into English. The data were examined thoroughly in order to arrive the various meanings of (DM) mashi. The study used spss system for statistical analysis. The researcher started calculating manually then sused the spss system. 


\subsection{Participants of study}

The sample of the study consists of all 65 English language Ph.D. Students in two sections in the University of Jordan. A total of 65 questionnaires were distributed 53 were collected 6 questionnaires have been neglected due to uncompleted answers and unreturned, 47 questionnaires data were suitable to be tested, table No1 represents the study sample demographic variables:

Table (1) Gender

\begin{tabular}{|l|c|c|}
\hline \multicolumn{1}{|c|}{ Gender } & Frequency & Percent \\
\hline MALE & 18 & 38.3 \\
\hline FEMALE & 29 & 61.7 \\
\hline Total & 47 & 100.0 \\
\hline Age & & 55.3 \\
\hline 25 AND LESS & 26 & 29.8 \\
\hline $26-35$ & 14 & 14.9 \\
\hline $36-45$ & 7 & 100.0 \\
\hline Total & 47 & \\
\hline
\end{tabular}

Table No. (1) Shows that $\% 61.7$ of the samples were females, $\% 38.3$ were males, $\% 55.3$ of the samples have less than 30 years old. \%36.1 have 30-40 years old.

\subsection{Presenting of data Analysis}

In data analysis the researcher focuses on the following:

1- Having some examples and sentences of the term "Mashi",

2- Translation the term "Mashi" according to its location in the sentence,

3- Brief analysis on the translated sentences depending on Frequency, means and standard deviations for the sample responses, which were calculated for each statement on the questionnaire. Where the researcher asked the participants about the use "Mashi" in daily interactions. The pragmatic meanings of "Mashi" were grouped and translated under different categories. The analysis in this study includes the Discourse Marker "Mashi" that occur in the Arabic speak communication. The following examples are taken from the speaking by some Jordanian people, which contain the word "Mashi", where the meaning of this term is different from one sentence to another according to the formula of speech.

\subsection{Examples of mashi}

Therefore, the researcher has discussing the term "Mashi" meanings for giving more elaboration on the subject. After a thorough careful examination of the collected data, the study found that the Arabic discourse marker "Mashi" have the following functions:

1- "Mashi" means "Good" as in "Mashi Alhal" (ماثشي الحال).

For example:

a) Ghadeer: "How are you?"

Khaled: "Mashi alhal" ماشثي الحال"I am good"

Depending on the example here, if somebody ask you that "How are you?", then sentence" Mashi alhal" means (Ok or I am good). Jordanians usually use the word "Mashi" when they asked about their selves, while you rarely find a Jordanian responding with a different answer. Jordanian responded many other questions with "Mashi alhal" such as the following:

b) Omar: How is your job?

Ammar: "Mashi alhal"

c) Odai: What do you think of your brother's marriage?

Anas: "Mashi alhal ma3o" (ماثشي الحال معا).

In some cases, the answer "Mashi alhal" gives a negative meaning, such as if the person is not in good situation, unless he responds with "Mashi alhal" to shorten the answer.

There are some examples of negative meaning of "Mashi alhal" in Jordanian culture:

a) A poor person (has nothing to eat) asked about his situations, and the poor person responds to him as "Mashi alhal". 
In this example, poor person answered as his situation is good, while in fact, he is not good because he has nothing to eat. Jordanian people (poor one of them) usually respond with this answer, which indicates the self-chastity of these people.

b) Ahmed is in a hard traffic accident. Someone asked him how is your car, and Ahmed responds with "Mashi halha".In this example, Ahmad responded as his car is in good situation, while his car is not good in order to that hard accident which happened to Ahmad. Therefore, Ahmed responded with this answer for brevity, and did not want to go into details with anyone.

c) Ali's father is sick. His cousin Omar asks Ali about his father, then Ali responded as "Mashi halo, Alhamdulelah" (ماشسي حاله، الحمد له). There, Ali answered as his father is good. In fact, his father is not good due to his sick. However, Ali answered his cousin like that in order to he do not worry about Ali's father.

2- "Mashi" means "Ok/ agree" as the following example:

Sam: "We have to travel tomorrow"

Mohammad: "Khalas Mashi" (خلص مانشي) which means "Ok, we will".

In this example, if someone need to know if you agree on something or not such as when Sam tell Mohammad that "We have to travel tomorrow", then this sentence "Khalas Mashi" gave you the answer, which indicates that "Ok, we will" (Agreement).

\section{Results and discussion}

\subsection{Presenting Study Results:}

(Likert Scale) was used in order to answer the questionnaire items based on the following values:

- Strongly Agree: (5) points

- Agree: (4) points

- Neutral: (3) points

- Disagree: (2) points.

- Strongly Disagree: (1) point.

The analysis in this study includes the Discourse Marker "Mashi" that occur in the Arabic speak communication.

\subsection{Discusion}

The following examples are taken from the speaking by some Arabic people from Arabi corpus website, which contain the word "Mashi", where the meaning of this term is different from one sentence to another according to the formula of speech. Therefore, the researcher has discussing the term "Mashi" meanings for giving more elaboration on the subject. After a thorough careful examination of the collected data, we found that the Arabic discourse marker "Mashi" have the following functions:

\section{Mashi Deferent Used:}

To identify Mashi deferent meanings, Means, Standard deviation, and correct answers percentage were retrieved, and reached the following results:

\begin{tabular}{|c|c|c|c|c|}
\hline Statement & $\begin{array}{l}\text { Used } \\
\text { for }\end{array}$ & Mean & $\begin{array}{c}\text { Std. } \\
\text { Deviation }\end{array}$ & $\begin{array}{c}\text { Correct Answers } \\
\text { percentage }\end{array}$ \\
\hline طردها خارج المحل فأومأت بر أسها و هي تبتسم وكأنها تقول ماثي & \multirow[t]{3}{*}{ threat } & \multirow[t]{3}{*}{4.106} & \multirow[t]{3}{*}{0.814} & \multirow[t]{3}{*}{$82.1 \%$} \\
\hline $\begin{array}{l}\text { Taradaha Kharij Almahal Fa?awma?t Bir?siha Wahia Tabtasim } \\
\text { Waka?anaha: Taqu:1 Mashi }\end{array}$ & & & & \\
\hline $\begin{array}{l}\text { He kicked her out of the shop, so she nodded her head with a } \\
\text { smile as she are saying Mashi }\end{array}$ & & & & \\
\hline
\end{tabular}


It is noted that the average Correct Answers percentage was (82.1\%) for the usage of MASHI as threat.

\begin{tabular}{|c|c|c|c|c|}
\hline Statement & Used for & Mean & $\begin{array}{c}\text { Std. } \\
\text { Deviation }\end{array}$ & $\begin{array}{l}\text { Correct Answers } \\
\text { percentage }\end{array}$ \\
\hline الصائغ جالس في دكانه يو ما من الأنيام إذا برجل أعجمي ماثشي في السوق بين & \multirow[t]{3}{*}{$\begin{array}{l}\text { Walk on } \\
\text { foot }\end{array}$} & \multirow[t]{3}{*}{4.53} & \multirow[t]{3}{*}{0.69} & \multirow[t]{3}{*}{$90.6 \%$} \\
\hline $\begin{array}{l}\text { Alsa:?gh Ja:ls Fi: Daka:nih Yawmaan Min Al?aya:m ?tha: } \\
\text { Birajl 'A } \text { A }^{\mathrm{c}} \text { jamiin Mashi Fi: Alsu:wq Bayn Alna:s }\end{array}$ & & & & \\
\hline $\begin{array}{l}\text { The jeweler is in his shop, while a foreign man Mashi in the } \\
\text { market among people. }\end{array}$ & & & & \\
\hline
\end{tabular}

It is noted that the average Correct Answers percentage was (90.6\%) for the usage of MASHI as Walk on foot.

\begin{tabular}{|c|c|c|c|c|}
\hline Statement & $\begin{array}{l}\text { Used } \\
\text { for }\end{array}$ & Mean & $\begin{array}{c}\text { Std. } \\
\text { Deviation }\end{array}$ & $\begin{array}{c}\text { Correct Answers } \\
\text { percentage }\end{array}$ \\
\hline 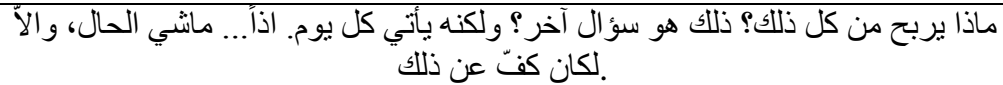 & \multirow[t]{3}{*}{ Benefit } & \multirow[t]{3}{*}{3.87} & \multirow[t]{3}{*}{1.09} & \multirow[t]{3}{*}{$77.4 \%$} \\
\hline $\begin{array}{l}\text { Matha: yarbah min kul thalik? thalik hua su?a:l a:khar? walakinah } \\
\text { ya?ti kula yaum. ethan... mashi alhal, wailla laka:na kf }{ }^{c} \mathrm{n} \text { thalik. }\end{array}$ & & & & \\
\hline $\begin{array}{l}\text { What does he gain from all this? Is that another question? However, } \\
\text { he comes every day. So ... Mashi things, otherwise he would stop }\end{array}$ & & & & \\
\hline
\end{tabular}

It is noted that the average Correct Answers percentage was (77.4\%) for the usage of MASHI as Benefit.

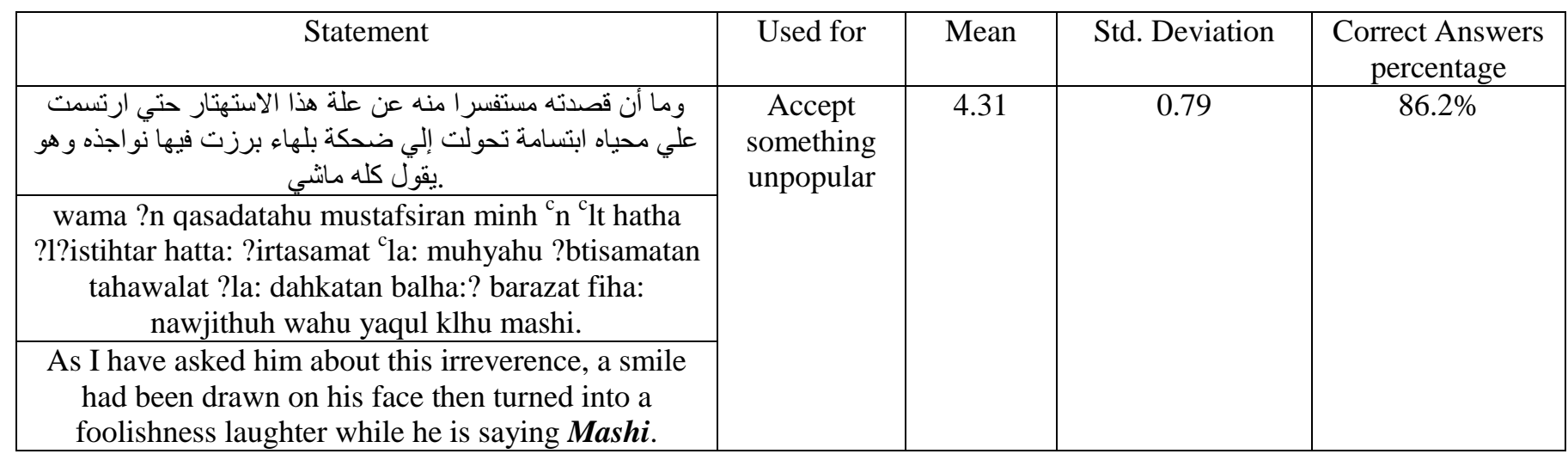

It is noted that the average Correct Answers percentage was (86.2\%) for the usage of MASHI as Accept something unpopular.

\begin{tabular}{|c|c|c|c|c|}
\hline Statement & Used for & Mean & Std. Deviation & $\begin{array}{c}\text { Correct Answers } \\
\text { percentage }\end{array}$ \\
\hline 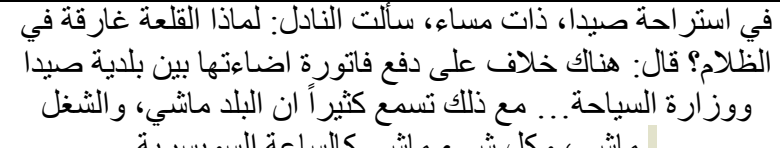 & \multirow[t]{3}{*}{$\begin{array}{l}\text { Things go } \\
\text { very well }\end{array}$} & \multirow[t]{3}{*}{4.30} & \multirow[t]{3}{*}{0.98} & \multirow[t]{3}{*}{$86.0 \%$} \\
\hline $\begin{array}{c}\text { Fi: aistirahat sayda:, dha:t masa:?n, sa?lt ?nadl: } \\
\text { limadha alqalc }{ }^{\mathrm{a}} \text { ah ghariqatan fi: althlam? qal: hunak } \\
\text { khilaf }{ }^{\mathrm{c}} \text { la: dafe }{ }^{\mathrm{c}} \text { fatu:rt ada:?teha: bayn baladiat sayda: } \\
\text { wawiza:rat alsiyahah... } \mathrm{m}^{\mathrm{c}} \text { dhlk tasma }{ }^{\mathrm{c}} \text { kthi:ran }{ }^{\mathrm{c}} \mathrm{n} \\
\text { albalad mashi, walshughl mashi, wakuli shay? mashi } \\
\text { kalsa: }{ }^{\mathrm{c}} \text { ah alsuwi:sriah. }\end{array}$ & & & & \\
\hline $\begin{array}{l}\text { At the Saida break, one evening, She asked the waiter: } \\
\text { Why is the castle soaked in darkness? He said: There is } \\
\text { disagreement over the payment of bill lit between the } \\
\text { Municipality of Saida and the Ministry of Tourism ... } \\
\text { However, you often hear that the country is Mashi, and } \\
\text { the work is Mashi, and everything is Mashi, like the } \\
\text { Swiss watch. }\end{array}$ & & & & \\
\hline
\end{tabular}


It is noted that the average Correct Answers percentage was (86.0\%) for the usage of MASHI as Things go very well.

\begin{tabular}{|c|c|c|c|c|}
\hline Statement & Used for & Mean & Std. Deviation & $\begin{array}{c}\text { Correct Answers } \\
\text { percentage }\end{array}$ \\
\hline الجاي ماثي وخليها ماثشية و العمر ماثشي و الأرض & \multirow[t]{3}{*}{ Conviction } & \multirow[t]{3}{*}{4.47} & \multirow[t]{3}{*}{0.65} & \multirow[t]{3}{*}{$89.4 \%$} \\
\hline $\begin{array}{c}\text { Alja:y mashi ukhali:ha mashiah wal }{ }^{\mathrm{c}} \text { umur mashi } \\
\text { wal?rd }\end{array}$ & & & & \\
\hline $\begin{array}{l}\text { Things coming next is Mashi, and let it Mashi, and } \\
\text { the age is Mashi, and the land }\end{array}$ & & & & \\
\hline
\end{tabular}

It is noted that the average Correct Answers percentage was (89.4\%) for the usage of MASHI as Conviction.

\begin{tabular}{|c|c|c|c|c|}
\hline Statement & Used for & Mean & Std. Deviation & $\begin{array}{c}\text { Correct Answers } \\
\text { percentage }\end{array}$ \\
\hline وحزن الغلابة مش ماشي ليه؟ & \multirow{3}{*}{ Complain } & \multirow{3}{*}{4.15} & \multirow{3}{*}{0.96} & \multirow{3}{*}{$83.0 \%$} \\
\hline wahuzun alghala:bah mish mashi li:h? & & & & \\
\hline And the sadness of poor people is not Mashi, why? & & & & \\
\hline
\end{tabular}

It is noted that the average Correct Answers percentage was (83.0\%) for the usage of MASHI as Complain.

\begin{tabular}{|c|c|c|c|c|}
\hline Statement & Used for & Mean & Std. Deviation & $\begin{array}{c}\text { Correct Answers } \\
\text { percentage }\end{array}$ \\
\hline لسا ماثشي على الدوا الي أعطاك إياه الدكتور؟ & \multirow[t]{3}{*}{ Continuation } & \multirow[t]{3}{*}{4.69} & \multirow[t]{3}{*}{0.56} & \multirow[t]{3}{*}{$93.8 \%$} \\
\hline Lissa: mashi: ${ }^{c}$ laa aldwa: ?li: ? ${ }^{c}$ tak ?ya:h alduktu:r? & & & & \\
\hline $\begin{array}{l}\text { Are you still Mashi on the medicine that the doctor } \\
\text { gave you? }\end{array}$ & & & & \\
\hline
\end{tabular}

It is noted that the average Correct Answers percentage was (93.8\%) for the usage of MASHI as Continuation.

\begin{tabular}{|c|c|c|c|c|}
\hline Statement & Used for & Mean & Std. Deviation & $\begin{array}{c}\text { Correct Answers } \\
\text { percentage }\end{array}$ \\
\hline خليك ماثشي الحيط الحيط & \multirow{3}{*}{ The behavior } & \multirow{3}{*}{4.30} & \multirow{3}{*}{0.96} & \multirow{3}{*}{$86.1 \%$} \\
\hline Khali:k mashi alhai:t alhai:t & & & & \\
\hline Keep Mashi beside the wall & & & & \\
\hline
\end{tabular}

It is noted that the average Correct Answers percentage was (86.1\%) for the usage of MASHI as The behavior.

\begin{tabular}{|c|c|c|c|c|}
\hline Statement & Used for & Mean & Std. Deviation & $\begin{array}{c}\text { Correct Answers } \\
\text { percentage }\end{array}$ \\
\hline قالتلها ماشي وضليت ماثسي & \multirow{3}{*}{ careless } & \multirow{3}{*}{4.36} & \multirow{3}{*}{0.82} & \multirow{3}{*}{$87.2 \%$} \\
\hline Qultilha: mashi wadali:t mashi & & & & \\
\hline I said to her Mashi, she keeps walking away & & & & \\
\hline
\end{tabular}

It is noted that the average Correct Answers percentage was (87.2\%) for the usage of MASHI as careless.

\begin{tabular}{|c|c|c|c|c|}
\hline Statement & Used for & Mean & Std. Deviation & $\begin{array}{c}\text { Correct Answers } \\
\text { percentage }\end{array}$ \\
\hline كيف حالك؟ فأجاب ماثسي الحال & \multirow[t]{3}{*}{ I am Ok } & \multirow[t]{3}{*}{4.49} & \multirow[t]{3}{*}{0.62} & \multirow[t]{3}{*}{$89.8 \%$} \\
\hline Ki:f halak? Fa?ja:b mashi alha:I & & & & \\
\hline $\begin{array}{c}\text { how are you? } \\
\text { He replied Mashi } \\
\end{array}$ & & & & \\
\hline
\end{tabular}

It is noted that the average Correct Answers percentage was (89.8\%) for the usage of MASHI as I am Ok.

\begin{tabular}{|c|c|c|c|c|}
\hline Statement & Used for & Mean & Std. Deviation & $\begin{array}{c}\text { Correct Answers } \\
\text { percentage }\end{array}$ \\
\hline Ji:b mack khubz, fa?ja:b mashi & $\begin{array}{c}\text { Approval of the } \\
\text { request }\end{array}$ & 4.55 & 0.58 & $91.1 \%$ \\
\cline { 1 - 1 } Bring bread with you, & & & \\
\hline He replied Mashi & & & \\
\hline
\end{tabular}

It is noted that the average Correct Answers percentage was (91.1\%) for the usage of MASHI as Approval of the request. 


\begin{tabular}{|c|c|c|c|c|}
\hline Statement & Used for & Mean & Std. Deviation & $\begin{array}{c}\text { Correct Answers } \\
\text { percentage }\end{array}$ \\
\hline جهز حالك اليوم، ماشي توكل على الله ,جاي & \multirow{3}{*}{ confirmation } & \multirow{3}{*}{4.45} & \multirow{3}{*}{0.77} & \multirow{3}{*}{$88.9 \%$} \\
\hline jahiz halak alywm, mashi tawakal ${ }^{\mathrm{c}}$ la: ?lla:h ,ja:y & & & & \\
\hline $\begin{array}{l}\text { Prepare yourself today Mashi. } \\
\text { Relay on God, coming }\end{array}$ & & & & \\
\hline
\end{tabular}

It is noted that the average Correct Answers percentage was (88.9\%) for the usage of MASHI as confirmation.

\begin{tabular}{|c|c|c|c|c|}
\hline Statement & Used for & Mean & $\begin{array}{c}\text { Std. } \\
\text { Deviation }\end{array}$ & $\begin{array}{c}\text { Correct Answers } \\
\text { percentage }\end{array}$ \\
\hline 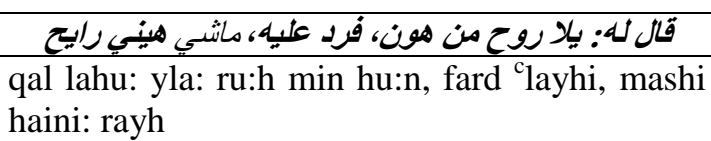 & \multirow[t]{2}{*}{$\begin{array}{l}\text { Execute an } \\
\text { order }\end{array}$} & \multirow[t]{2}{*}{4.47} & \multirow[t]{2}{*}{0.65} & \multirow[t]{2}{*}{$89.4 \%$} \\
\hline $\begin{array}{l}\text { He said to him: "go away" he replied. } \\
\text { Mashi I'm going }\end{array}$ & & & & \\
\hline
\end{tabular}

It is noted that the average Correct Answers percentage was (89.4\%) for the usage of MASHI as Execute an order.

\begin{tabular}{|c|c|c|c|c|}
\hline Statement & Used for & Mean & Std. Deviation & $\begin{array}{c}\text { Correct } \\
\text { Answers } \\
\text { percentage }\end{array}$ \\
\hline بلنا تلعب كرة البيوم، فرب عليه صلابقِه: ماشسي ما في مشكلة بس & \multirow{3}{*}{$\begin{array}{c}\text { Accept } \\
\text { something that } \\
\text { is not favored }\end{array}$} & \multirow[t]{3}{*}{4.28} & \multirow[t]{3}{*}{0.74} & \multirow[t]{3}{*}{$85.5 \%$} \\
\hline $\begin{array}{l}\text { bidna nal }{ }^{\mathrm{c}} \text { ab kurah alyawm, fard }{ }^{\mathrm{c}} \text { layh sadi:quh: mashi } \\
\text { ma: fi: mushkilah bas alwaqt mut?khir }\end{array}$ & & & & \\
\hline $\begin{array}{l}\text { We had to play the ball today. } \\
\text { his friend replied: "Mashi but it's late". }\end{array}$ & & & & \\
\hline
\end{tabular}

It is noted that the average Correct Answers percentage was (85.5\%) for the usage of MASHI as Accept something that is not favored.

\begin{tabular}{|c|c|c|c|c|}
\hline Statement & Used for & Mean & Std. Deviation & $\begin{array}{c}\text { Correct Answers } \\
\text { percentage }\end{array}$ \\
\hline كنت ماشسي وفجأة توقفتت عند الجسر لأرى ماذا يحلث هناك & \multirow{3}{*}{ walking } & \multirow[t]{3}{*}{4.63} & \multirow[t]{3}{*}{0.53} & \multirow[t]{3}{*}{$92.6 \%$} \\
\hline $\begin{array}{l}\text { kunt mashi wafaj?ah tawaqafat }{ }^{c} \text { ind aljisr li?raa madha } \\
\text { yahduth huna:k }\end{array}$ & & & & \\
\hline $\begin{array}{l}\text { I was Mashi and suddenly I stopped at the bridge to } \\
\text { see what was happening there }\end{array}$ & & & & \\
\hline
\end{tabular}

It is noted that the average Correct Answers percentage was (92.6\%) for the usage of MASHI as walking.

\begin{tabular}{|c|c|c|c|c|}
\hline Statement & Used for & Mean & Std. Deviation & Correct Answers percentage \\
\hline ماشي حالهيا الحمد لله & It is $\mathrm{OK}$ & 4.45 & 0.69 & $88.9 \%$ \\
\hline $\begin{array}{c}\text { kayf alsayarah macak? mashi ha:lha alhamd lila:h } \\
\text { Is the car Good } \\
\text { it is Mashi }\end{array}$ & & & & \\
\hline
\end{tabular}

It is noted that the average Correct Answers percentage was (88.9\%) for the usage of MASHI as It is OK.

\begin{tabular}{|c|c|c|c|c|}
\hline Statement & Used for & Mean & Std. Deviation & $\begin{array}{c}\text { Correct Answers } \\
\text { percentage }\end{array}$ \\
\hline لا تلسى تروح على السوق اليوم ماتشي مشي ماسي & \multirow[t]{3}{*}{$\begin{array}{l}\text { End the } \\
\text { conversation }\end{array}$} & \multirow[t]{3}{*}{4.34} & \multirow[t]{3}{*}{0.73} & \multirow[t]{3}{*}{$86.8 \%$} \\
\hline $\begin{array}{l}\text { la tansa: taru:h }{ }^{c} \text { la: alsu:q alyawm mashi mashi mish } \\
\text { nasi: }\end{array}$ & & & & \\
\hline $\begin{array}{l}\text { Do not forget to travel on the market today } \\
\text { Mashi, Mashi not forgetting }\end{array}$ & & & & \\
\hline
\end{tabular}


It is noted that the average Correct Answers percentage was (86.8\%) for the usage of MASHI as OK.

\begin{tabular}{|c|c|c|c|c|}
\hline Statement & Used for & Mean & $\begin{array}{c}\text { Std. } \\
\text { Deviation }\end{array}$ & $\begin{array}{c}\text { Correct Answers } \\
\text { percentage }\end{array}$ \\
\hline ماشي على تعليمات الددرب في النادي؟ & \multirow{3}{*}{$\begin{array}{l}\text { Following coach's } \\
\text { instructions }\end{array}$} & \multirow[t]{3}{*}{4.38} & \multirow[t]{3}{*}{0.85} & \multirow[t]{3}{*}{$87.7 \%$} \\
\hline $\begin{array}{c}\text { mashi }{ }^{c} \text { la: tacli:ma:t almudarib fi: } \\
\text { ?lna:di:? }\end{array}$ & & & & \\
\hline $\begin{array}{c}\text { Mashi, by coach's instructions at the } \\
\text { club? }\end{array}$ & & & & \\
\hline
\end{tabular}

It is noted that the average Correct Answers percentage was (87.7\%) for the usage of MASHI as Following coach's instructions.

\begin{tabular}{|c|c|c|c|c|}
\hline Statement & Used for & Mean & Std. Deviation & Correct Answers \\
\hline ماشسي، انـا راح اتصرف معك & \multirow[t]{3}{*}{ Threat } & \multirow[t]{3}{*}{4.43} & \multirow[t]{3}{*}{0.74} & \multirow[t]{3}{*}{$88.5 \%$} \\
\hline mashi, ?na: ra:h ?tasaraf macak & & & & \\
\hline Mashi, I'm going to deal with you & & & & \\
\hline
\end{tabular}

It is noted that the average Correct Answers percentage was $(88.5 \%)$ for the usage of MASHI as Threat.

\begin{tabular}{|c|c|c|c|c|}
\hline Statement & Used for & Mean & Std. Deviation & $\begin{array}{c}\text { Correct Answers } \\
\text { percentage }\end{array}$ \\
\hline mashi wamsh shayif quad:mi: & Anger & 4.32 & 0.84 & $86.4 \%$ \\
\hline Mashi and I'm not Seeing anything in front of me & & & \\
\hline
\end{tabular}

It is noted that the average Correct Answers percentage was (86.4\%) for the usage of MASHI as Anger.

\begin{tabular}{|c|c|c|c|c|}
\hline Statement & Used for & Mean & Std. Deviation & $\begin{array}{c}\text { Correct Answers } \\
\text { percentage }\end{array}$ \\
\hline وضعت عشاءك في الفرن، ماثـي? & \multirow{3}{*}{ Confirmation } & \multirow{3}{*}{4.38} & \multirow{3}{*}{0.64} & \multirow{3}{*}{$87.7 \%$} \\
\hline Wada $^{c} \mathrm{t}^{\mathrm{c}}$ sha:?k fi: alfurn, mashi? & & & & \\
\hline I Put your dinner in the oven, Mashi? & & & & \\
\hline
\end{tabular}

It is noted that the average Correct Answers percentage was (87.7\%) for the usage of MASHI as Confirmation.

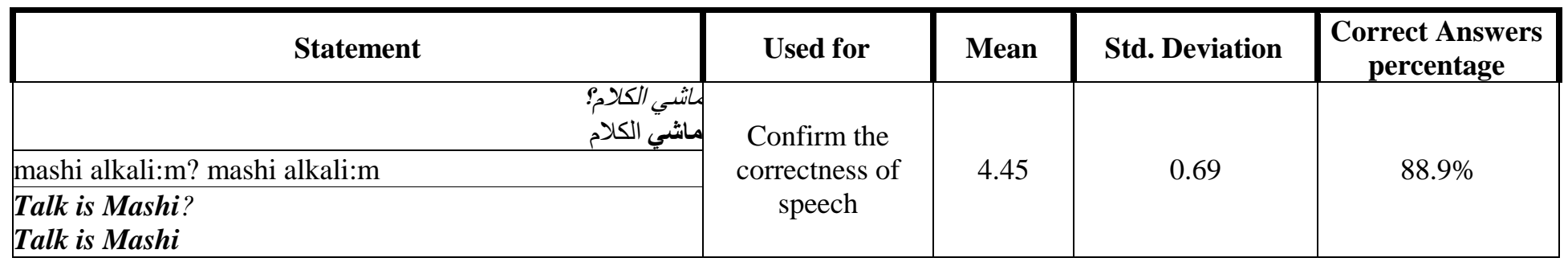

It is noted that the average Correct Answers percentage was $(88.9 \%)$ for the usage of MASHI as Confirm the correctness of speech.

\begin{tabular}{|c|c|c|c|c|}
\hline Statement & Used for & Mean & Std. Deviation & $\begin{array}{c}\text { Correct Answers } \\
\text { percentage }\end{array}$ \\
\hline كم السرعة الي كنت ماشي فيها؟ & \multirow{3}{*}{ The Movement } & \multirow{3}{*}{4.55} & \multirow{3}{*}{0.54} & \multirow{3}{*}{$91.1 \%$} \\
\hline kam alsirc ah ?li: kunt mashi fi:ha:? & & & & \\
\hline How fast you were Mashi? & & & & \\
\hline
\end{tabular}

It is noted that the average Correct Answers percentage was (91.1\%) for the usage of MASHI as The Movement. 


\begin{tabular}{|c|c|c|c|c|}
\hline Statement & Used for & Mean & Std. Deviation & $\begin{array}{c}\text { Correct Answers } \\
\text { percentage }\end{array}$ \\
\hline هذا الرجل ماشسي دغري. & \multirow{3}{*}{ The behavior } & \multirow{3}{*}{4.51} & \multirow{3}{*}{0.62} & \multirow{3}{*}{$90.2 \%$} \\
\hline hadha alrajul mashi dughri: & & & & \\
\hline This Guy is Mashi straight ahead. & & & & \\
\hline
\end{tabular}

It is noted that the average Correct Answers percentage was (90.2\%) for the usage of MASHI as The behavior.

\begin{tabular}{|c|c|c|c|c|}
\hline Statement & Used for & Mean & Std. Deviation & $\begin{array}{c}\text { Correct Answers } \\
\text { percentage }\end{array}$ \\
\hline ماثسي على القانون بحذ/فيره & \multirow{3}{*}{ Commitment } & \multirow{3}{*}{4.55} & \multirow{3}{*}{0.54} & \multirow{3}{*}{$91.1 \%$} \\
\hline mashi ${ }^{c}$ ala: alqa:nu:n bihadha:fi:ruh & & & & \\
\hline He is Mashi on the law very carefully & & & & \\
\hline
\end{tabular}

It is noted that the average Correct Answers percentage was (91.1\%) for the usage of MASHI as Commitment.

\begin{tabular}{|c|c|c|c|c|}
\hline Statement & Used for & Mean & Std. Deviation & $\begin{array}{c}\text { Correct Answers } \\
\text { percentage }\end{array}$ \\
\hline الحظظ ماشي مغنا تعام & \multirow{3}{*}{$\begin{array}{l}\text { Pleasure and } \\
\text { optimism }\end{array}$} & \multirow{3}{*}{4.34} & \multirow{3}{*}{0.64} & \multirow{3}{*}{$86.8 \%$} \\
\hline alhath mashi ma ${ }^{c}$ ana tamam & & & & \\
\hline Luck is Mashi with us very good & & & & \\
\hline
\end{tabular}

It is noted that the average Correct Answers percentage was (86.8\%) for the usage of MASHI as Pleasure and optimism.

\begin{tabular}{|l|c|c|c|c|}
\hline \multicolumn{1}{|c|}{ Statement } & Used for & Mean & Std. Deviation & $\begin{array}{c}\text { Correct Answers } \\
\text { percentage }\end{array}$ \\
\hline \multicolumn{1}{|c|}{ Straightness } & 4.38 & 0.68 & $87.7 \%$ \\
\hline Altari:q mashi ma ${ }^{c}$ na & & & \\
\hline The Road is Mashi with us & & & \\
\hline
\end{tabular}

It is noted that the average Correct Answers percentage was (87.7\%) for the usage of MASHI as Straightness.

The results indicated that the use of the word MASHI was understood to $87.9 \%$ by the sample of the study and the following table shows the study, Continuation is the most understood usage of the word Mashi, 93.78\% While benefit was the lowest understood usage of the word Mashi, 77.39\%.

\begin{tabular}{|l|r|}
\hline Usage & percentage \\
\hline Continuation & $93.78 \%$ \\
\hline the movement & $92.61 \%$ \\
\hline Commitment & $91.06 \%$ \\
\hline The movement & $91.06 \%$ \\
\hline Approval of the application & $91.06 \%$ \\
\hline Walk on foot & $90.64 \%$ \\
\hline A behavior & $90.21 \%$ \\
\hline Not bad & $89.79 \%$ \\
\hline Contentment & $89.36 \%$ \\
\hline Execute an order & $89.36 \%$ \\
\hline Approval and confirmation & $88.94 \%$ \\
\hline Confirm the correctness of speech & $88.94 \%$ \\
\hline Contentment & $88.94 \%$ \\
\hline A threat & $88.51 \%$ \\
\hline
\end{tabular}




\begin{tabular}{|l|r|}
\hline Discipline & $87.66 \%$ \\
\hline confirmation & $87.66 \%$ \\
\hline Straightness & $87.66 \%$ \\
\hline Take care & $87.23 \%$ \\
\hline Pleasure and optimism & $86.81 \%$ \\
\hline End the conversation & $86.81 \%$ \\
\hline Anger & $86.38 \%$ \\
\hline Accept something that is not favored & $86.22 \%$ \\
\hline the behavior & $86.09 \%$ \\
\hline Things go well & $85.96 \%$ \\
\hline Accept something that is not favored & $85.53 \%$ \\
\hline The grumble & $82.98 \%$ \\
\hline the threat & $82.13 \%$ \\
\hline Benefit & $77.39 \%$ \\
\hline Average & $\mathbf{8 7 . 9 \%}$ \\
\hline
\end{tabular}

\section{Conclusion}

The study has provided an analysis on the pragmatic functions of the (DM) mashi which is employed by Arabic speakers in 28 functions. The functions are: Approval, walking, behavior, not bad, contentment, execute, approval and confirmation, a threat, etc. the analysis showed that the use of the word MASHI was understood to $87.9 \%$ by the sample of the study and the following table shows the study, Continuation is the most understood usage of the word Mashi, 93.78\% While benefit was the lowest understood usage of the word Mashi, 77.39\%.

\subsection{Recommendations}

In the light of the findings, the study recommends the following: The need to take into account the meanings and uses of different words in Arabic. The researcher found that the Arabic word has many different uses that may vary according to the local dialect of the state. It also vary according to the text in which it was mentioned.

\section{References}

Al Rousan, Rafat. (2015). 'The use of discourse marker "maS nafsak" in Saudi Arabic: a pragmatic perspective'. International Journal of Linguistics, 7(3): 33-48.

Alami, Manizheh. (2015). 'Pragmatic functions of discourse markers: a review of related literature'. International Journal on Studies in English Language and Literature, 3(3): 1-10.

Alazzawie, Abdulkhaliq. (2014). 'Yamawwad: a discourse and pragmatic marker in Iraqi Arabic'. World Journal of English Language, 4(2): 30-39.

Al-Ghoweri, Helen. (2016). 'Pragmatic functions of alalakom'allah (may god elevate you) in modern Arabic language'. Imperial Journal of Interdisciplinary Research (IJIR), 2(6): 271-274.

Ariel, Mira. (2009). 'Discourse, grammar, discourse'. Discourse Studies, 11(1): 5-36.

Brown, Gillian, Kersten Malmkjær and John Williams. (1996). Performance and Competence in Second Language Acquisition. Cambridge: Cambridge University Press.

Castro, Claudia. (2009). The use and functions of discourse markers in EFL classroom interaction. Profile Issues in Teachers Professional Development, Bogotá, Colombia.

Chomsky, Noam. (1981). The Essential Chomsky. New Yorkhttps://en.wikipedia.org/wiki/Santa_Barbara,_California: The New York Press.

Chomsky, Noam. (1986). Knowledge of Language: Its Nature, Origin, and Use. California: Greenwood Publishing Group.

Chuang, Fei-Yu. (2017). Discourse Markers. Globalpad, Openhouse. https://warwick.ac.uk/fac/soc/al/globalpad/openhouse/academicenglishskills/grammar/discourse/ (Retrived on 12 November 2018).

De Aquino, Carla. (2011). 'Pragmatic competence'. Belt Journal, 2(2): 140-153.

Djigunovic, Jelena. (2007). 'Definning comunicative competance'. Metodika, 8(1): 94-103. 
Fagari, Mokhtar. (2013). 'The concept of discourse: between the original Western reference and rooted in the Arabic language'. University of Taibah Journal of Arts and Humanities, 3: 532-584.

Farouk, Sultani. (2018). 'Synthetic studies in Arabic linguistic heritage'. Journal of Al-Omda of Linguistics and Discourse Analysis, 3: 399-409.

Feng, Li. (2010). 'Discourse markers in English writing'. The Journal of International Social Research, 3(11): 299305.

Fraser, Bruce. (1999). ' What are discourse markers?'. Journal of Pragmatics, 31: 931-952.

Hellermann, John and Andrea Vergun. (2007). 'Language which is not taught: the discourse marker use of beginning adult learners of English'. Journal of Pragmatics, 39: 157-179.

Hutchinson, Ben. (2004). 'Acquiring the meaning of discourse markers'. Proceedings of the 42nd Annual Meeting on Association for Computational Linguistics.

Jucker, Andreas. (1993). 'The discourse marker well: a relevance-theoretical account'. Journal of Pragmatics, 19(5): 435-452.

Kanakri, Mahmoud and Ahmad Al-Harahsheh. (2013). 'The discourse analysis and pragmatics of Pa:di in modern Arabic language'. International Journal of English Linguistics, 3(6): 59-63.

Kawamo, Masahito, Akira Himazu and keshi Kawabata. (1996). 'a phonological study on Japanese discourse markers'. Language, Information and Computation, 11: 297-306.

Littlemore, Jeannette and Graham Low. (2006). 'Metaphoric competence, second language learning, and communicative language ability.' Applied Linguistics 27(2): 268-294.

Lyons, Jhon. (1995). Linguistic Symantics. Cambridge: Cambridge University Press.

Marmorstein, Michal. (2016). 'Getting to the point: the discourse marker yaSni (lit. "it means") in unplanned discourse in Cairene Arabic'. Journal of Pragmatics, 96: 60-79.

Mehawesh, Mohammad and Abdullah Jaradat. (2015). 'Inshallah: extensive flouting of grice's maxim of quality'. Asian Social Science, 11(4): 319-327.

Piurko, Elena. (2015). Discourse markers: their function and distribution in the media and legal discourse. Unpublished MA Thesis, Lithuanian University of Educational Sciences, Vilnius, Lithuania.

Radford, Andrew. (2009). An Introduction to English Sentence Structure. Cambridge: Cambridge University Press.

Rueda, Tella. (2006). 'Developing pragmatic competance in a forgin language'. Colombian Applied Linguistic Journal, 8: 169-182.

Schiffrin, Deborah. (2005). 'Discourse markers: language, meaning, and context'. The Handbook of Discourse Analysis, 54-75.

Shabi, Zaynab. (2016). The effect of linguistic interplay between the general and the descriptive in written expression. Unpublished MA Thesis, University of Qasdi Merbah, Ouargla, Algeria.

Vickov, Gloria and Eva Jakupčević. (2017). 'Discourse markers in non-native efl teacher talk'. Studies in Second Language Learning and Teaching, 7(4): 649-671.

\section{Appendix}

Transliteration symbols for Arabic vowels and some consonants

\begin{tabular}{|c|c|c|c|}
\hline Arabic alphabet & Symbol & Example & Meaning \\
\hline 4 & $?$ & ?amal & hope \\
\hline$\dot{H}$ & th & tha ${ }^{\mathrm{c}} \mathrm{lab}$ & fox \\
\hline ج & $\bar{j}$ & jamal & camel \\
\hline$\tau$ & $\mathrm{h}$ & $\mathrm{hub}$ & love \\
\hline$\dot{\tau}$ & $\mathrm{kh}$ & khubz & bread \\
\hline$\dot{j}$ & $\mathrm{dh}$ & dhahab & gold \\
\hline j & $\mathrm{z}$ & zi:t & oil \\
\hline ش ش & sh & shams & sun \\
\hline ص & $\mathrm{s}$ & s ayf & summer \\
\hline ض & $\mathrm{d}$ & d ayf & guest \\
\hline b & $\mathrm{t}$ & $\mathrm{ti}: \mathrm{n}$ & mud \\
\hline b & $\mathrm{TH}$ & THuhr & noon \\
\hline$\varepsilon$ & $\mathrm{c}$ & cabd & slave \\
\hline$\dot{\varepsilon}$ & gh & gharb & west \\
\hline ق & $q$ & qalam & pencil \\
\hline و & $\mathrm{W}$ & ward & rose \\
\hline
\end{tabular}




\begin{tabular}{|c|c|c|c|}
\hline ين & $\mathrm{y}$ & yawm & day \\
\hline (فتحة) & $\mathrm{a}$ & kataba & he wrote \\
\hline (ضمة) & $\mathrm{u}$ & kutub & books \\
\hline (كسرة) & $\mathrm{i}$ & $\sin$ & tooth \\
\hline مد طويل ا/ى & $\mathrm{a}:$ & ka:tib & writer \\
\hline ضمة طويلة و & $\mathrm{u}:$ & fu:l & beans \\
\hline كسرة طويلة ي & i: & fi:1 & elephant \\
\hline \multirow{2}{*}{$\begin{array}{c}\text { Diphthongs } \\
\text { (أصوات عركبة) }\end{array}$} & aw & mawt & death \\
\hline & ay & bayt & house \\
\hline
\end{tabular}

\section{تحية طبية وبعد...}

يقوم الباحث بإجر اء در اسة للتعرف على المعاني المختلفة لكلمة ماشيه بانيه

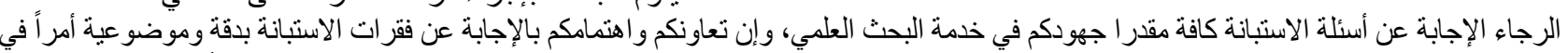
غاية الأهمية لمساندة الدراسة علة علمياً.

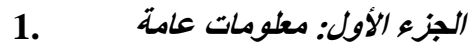

) عند الاختيار المناسب:Xارجو التكرم بوضع اشارة (

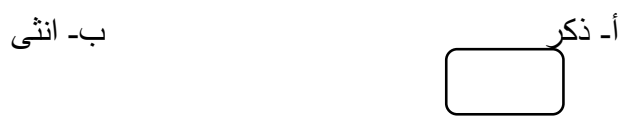

-

$$
\text { ب- انثى }
$$

أـ اقل من 30 سنة

ب- من 30-40 سنة

د- أكثر من 50 سنة

ج- من أن أن من -40 سنة

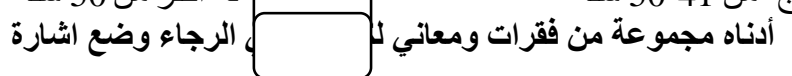

حسب مدى صحة وظيفة كلمة ماشي في الجملة.ل

2 - الفئة العمرية:

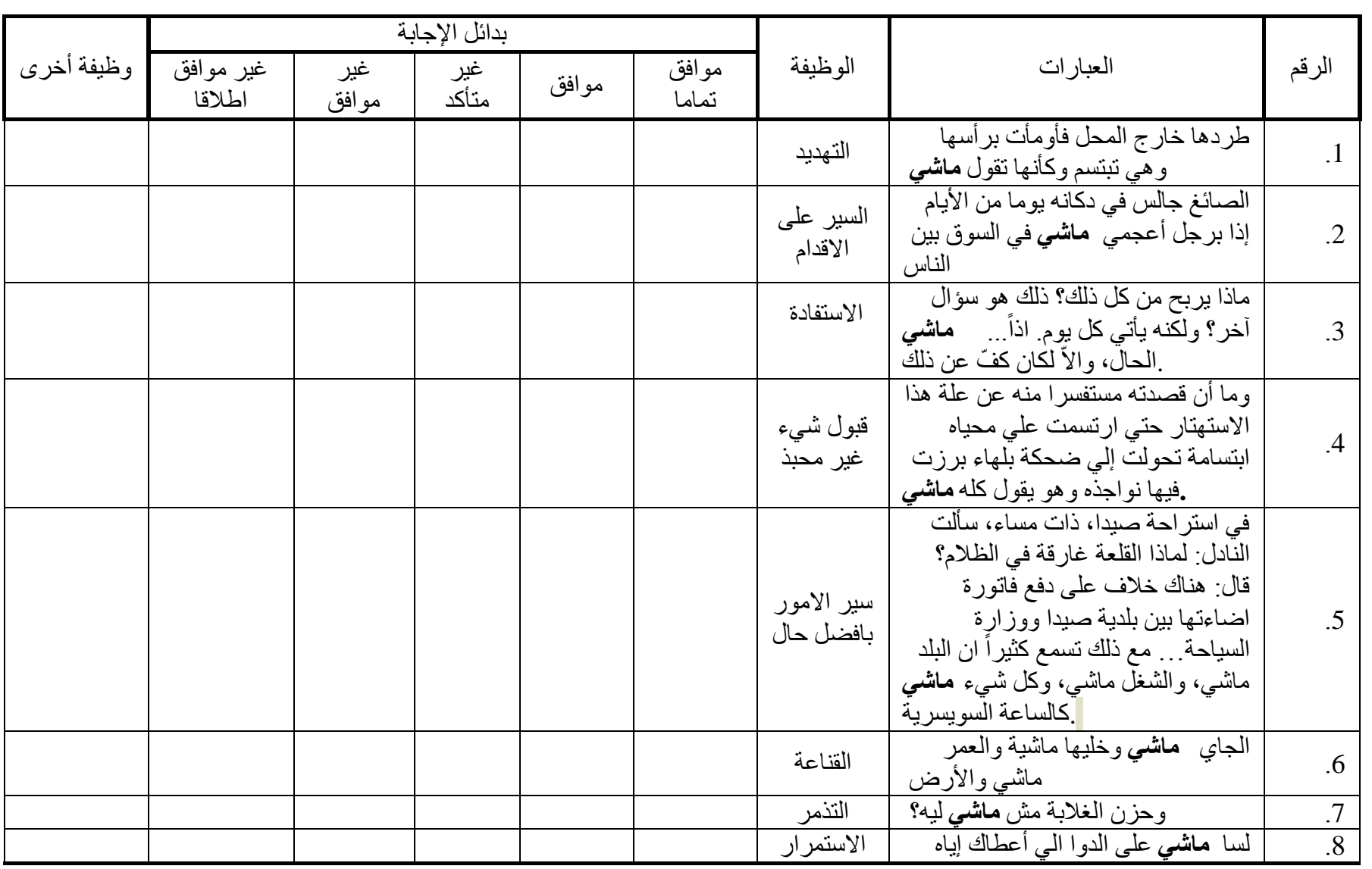




\begin{tabular}{|c|c|c|c|c|c|c|c|c|}
\hline \multirow[b]{2}{*}{ وظيفة أخرى } & \multicolumn{5}{|c|}{ بدائل الإجابة } & \multirow[b]{2}{*}{ الوظيفة } & \multirow[b]{2}{*}{ 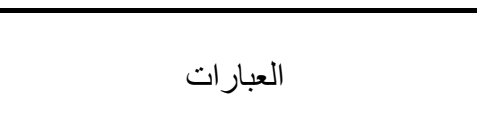 } & \multirow[b]{2}{*}{ 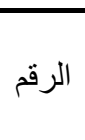 } \\
\hline & غير مو افق & مو افق & متأكد & 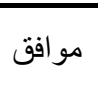 & تمواما & & & \\
\hline & & & & & & & الدكتور؟ & \\
\hline & & & & & & السلوك & خليك ماثشي الحيط الحيط & .9 \\
\hline & & & & & & الاكتر اث & قلتلها مانشي وضليت ماثي & .10 \\
\hline & & & & & & ليس سيء & كيف حالك؟ فأجاب ماشي الحال & .11 \\
\hline & & & & & & على الطلب الققة & جيب معاك خبز، فأجاب ماثي & .12 \\
\hline & & & & & & و الموافقة & جهز حالك اليوم، ماشي توكل على الله & .13 \\
\hline & & & & & & تنفيذ امر & قال له: يلا روح من هون، فرد عليه، & .14 \\
\hline & & & & & & قبول شيء محبذ & 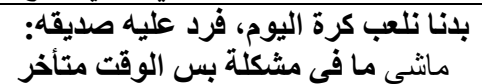 & .15 \\
\hline & & & & & & الحركة & 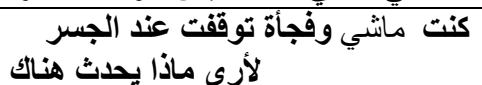 & .16 \\
\hline & & & & & & القناعة & ماشى حالها الحمد لله كيف السيارة معك؟ & .17 \\
\hline & & & & & & الحديث & ماثي ماثشي مشى ناسي على السوق اليوم & .18 \\
\hline & & & & & & الانضباط & مانشي على تُعليمات الَّدرب في النادي؟ & .19 \\
\hline & & & & & & تهديد & مانشي، انا راح اتصرف معك & .20 \\
\hline & & & & & & الغضب & مانشي ومش شايف قدامى & .21 \\
\hline & & & & & & التأكيد & وضعت عشاءوك في الفرن، ماثي؟؟ & .22 \\
\hline & & & & & & تأكيد على & 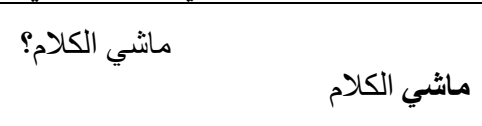 & .23 \\
\hline & & & & & & الحركة & كم السرعة الي كنت مانشي فيها؟ & .24 \\
\hline & & & & & & السلوك & هذا الرجل ماشي دغري. & .25 \\
\hline & & & & & & الالتز ام & مانشي على القانون بذذافيره & .26 \\
\hline & & & & & & و التفرور & الحظ مانشي معنا تمام & .27 \\
\hline & & & & & & الاستقامة & الطريق ماشي مغنا & .28 \\
\hline
\end{tabular}

Dear ........Greetings,

Questionnaire

Accordingly, please read it and answer the following questions carefully and objectively, ensuring that the information collected is classified and it will be used for scientific purposes only.

Part (A) mark the suitable answer by putting litter (X) put it in the table it is better

\begin{tabular}{|l|l|l|}
\hline Categories \\
1- What is better categories describe \\
your age?
\end{tabular}


Below is a set of paragraphs and meanings of the word walker. Please put an $\mathrm{X}$ sign according to the correct function of the word walk in the sentence.

\begin{tabular}{|c|c|c|c|c|c|c|c|c|}
\hline No & Statement & Function & $\begin{array}{c}\text { Totally } \\
\text { Agree }\end{array}$ & Agree & $\begin{array}{l}\text { Not } \\
\text { sure }\end{array}$ & $\begin{array}{c}\text { Not } \\
\text { agree }\end{array}$ & $\begin{array}{c}\text { Totaly } \\
\text { Not } \\
\text { agree }\end{array}$ & $\begin{array}{c}\text { Other } \\
\text { functional }\end{array}$ \\
\hline 1. & $\begin{array}{c}\text { He Kicked her out } \\
\text { of the shop, so she } \\
\text { nodded her head } \\
\text { with a smile as } \\
\text { she are saying } \\
\text { Mashi }\end{array}$ & Threat & & & & & & \\
\hline 2. & $\begin{array}{l}\text { The jeweler is in } \\
\text { his shop, while a } \\
\text { foreign man } \\
\text { Mashi in the } \\
\text { market among } \\
\text { people. }\end{array}$ & $\begin{array}{c}\text { Walk by } \\
\text { feet }\end{array}$ & & & & & & \\
\hline 3. & $\begin{array}{l}\text { What does he gain } \\
\text { from all this? Is } \\
\text { that another } \\
\text { question? } \\
\text { However, he } \\
\text { comes every day. } \\
\text { So ... Mashi } \\
\text { things, otherwise } \\
\text { he would stop }\end{array}$ & Benefit & & & & & & \\
\hline 4. & $\begin{array}{l}\text { As I have asked } \\
\text { him about this } \\
\text { irreverence, a } \\
\text { smile had been } \\
\text { drawn on his face } \\
\text { then turned into a } \\
\text { foolishness } \\
\text { laughter while he } \\
\text { is saying Mashi. }\end{array}$ & $\begin{array}{c}\text { Accept } \\
\text { somethin } \\
\text { g } \\
\text { unpopula } \\
\text { r }\end{array}$ & & & & & & \\
\hline 5. & $\begin{array}{c}\text { At the Saida } \\
\text { break, one } \\
\text { evening, She } \\
\text { asked the waiter: } \\
\text { Why is the castle } \\
\text { soaked in } \\
\text { darkness? He said: } \\
\text { There is } \\
\text { disagreement over } \\
\text { the payment of } \\
\text { bill lit between the } \\
\text { Municipality of } \\
\text { Saida and the } \\
\text { Ministry of } \\
\text { Tourism ... } \\
\text { However, you } \\
\text { often hear that the } \\
\text { country is Mashi, } \\
\text { and the work is }\end{array}$ & $\begin{array}{c}\text { Things } \\
\text { go very } \\
\text { well }\end{array}$ & & & & & & \\
\hline
\end{tabular}




\begin{tabular}{|c|c|c|c|c|c|c|c|c|}
\hline No & Statement & Function & $\begin{array}{l}\text { Totally } \\
\text { Agree }\end{array}$ & Agree & $\begin{array}{l}\text { Not } \\
\text { sure }\end{array}$ & $\begin{array}{l}\text { Not } \\
\text { agree }\end{array}$ & $\begin{array}{l}\text { Totaly } \\
\text { Not } \\
\text { agree }\end{array}$ & $\begin{array}{c}\text { Other } \\
\text { functional }\end{array}$ \\
\hline & $\begin{array}{l}\text { Mashi, and } \\
\text { everything is } \\
\text { Mashi, like the } \\
\text { Swiss watch. }\end{array}$ & & & & & & & \\
\hline 6. & $\begin{array}{l}\text { Things coming } \\
\text { next is Mashi, and } \\
\text { let it Mashi, and } \\
\text { the age is Mashi, } \\
\text { and the land }\end{array}$ & $\begin{array}{c}\text { Convictio } \\
n\end{array}$ & & & & & & \\
\hline 7. & $\begin{array}{l}\text { And the sadness } \\
\text { of poor people are } \\
\text { not Mashi, why? }\end{array}$ & $\begin{array}{c}\text { Complai } \\
n\end{array}$ & & & & & & \\
\hline 8. & $\begin{array}{c}\text { Are you still } \\
\text { Mashi on the } \\
\text { medicine that the } \\
\text { doctor gave you? }\end{array}$ & $\begin{array}{c}\text { Continua } \\
\text { tion }\end{array}$ & & & & & & \\
\hline 9. & $\begin{array}{c}\text { Keep Mashi } \\
\text { beside the wall }\end{array}$ & $\begin{array}{c}\text { The } \\
\text { behavior }\end{array}$ & & & & & & \\
\hline 10. & $\begin{array}{c}\text { I said to her } \\
\text { Mashi, she keeps } \\
\text { walking away }\end{array}$ & careless & & & & & & \\
\hline 11. & $\begin{array}{c}\text { how are you? } \\
\text { He replied Mashi }\end{array}$ & A am Ok & & & & & & \\
\hline 12. & $\begin{array}{c}\text { Bring bread with } \\
\text { you, } \\
\text { He replied Mashi }\end{array}$ & $\begin{array}{l}\text { Approval } \\
\text { of the } \\
\text { request }\end{array}$ & & & & & & \\
\hline 13. & $\begin{array}{l}\text { Prepare yourself } \\
\text { today Mashi. } \\
\text { Relay on God, } \\
\text { coming }\end{array}$ & $\begin{array}{c}\text { confirma } \\
\text { tion }\end{array}$ & & & & & & \\
\hline 14. & $\begin{array}{l}\text { He said to him: } \\
\text { "go away" he } \\
\text { replied. } \\
\text { Mashi I'm going }\end{array}$ & $\begin{array}{l}\text { Execute } \\
\text { an order }\end{array}$ & & & & & & \\
\hline 15. & $\begin{array}{l}\text { We had to play } \\
\text { the ball today. } \\
\text { his friend replied: } \\
\text { "no problem but } \\
\text { it's late". }\end{array}$ & $\begin{array}{c}\text { Accept } \\
\text { somethin } \\
\text { g that is } \\
\text { not } \\
\text { favored }\end{array}$ & & & & & & \\
\hline 16. & $\begin{array}{c}\text { I was Mashi and } \\
\text { suddenly I } \\
\text { stopped at the } \\
\text { bridge to see what } \\
\text { was happening } \\
\text { there }\end{array}$ & $\begin{array}{c}\text { الحركة } \\
\text { walking }\end{array}$ & & & & & & \\
\hline 17. & $\begin{array}{l}\text { Is the car Good } \\
\text { It is Mashi }\end{array}$ & It is $\mathrm{OK}$ & & & & & & \\
\hline 18. & $\begin{array}{l}\text { Do not forget to } \\
\text { travel on the } \\
\text { market today }\end{array}$ & $\mathrm{OK}$ & & & & & & \\
\hline
\end{tabular}




\begin{tabular}{|c|c|c|c|c|c|c|c|c|}
\hline No & Statement & Function & $\begin{array}{l}\text { Totally } \\
\text { Agree }\end{array}$ & Agree & $\begin{array}{l}\text { Not } \\
\text { sure }\end{array}$ & $\begin{array}{l}\text { Not } \\
\text { agree }\end{array}$ & $\begin{array}{c}\text { Totaly } \\
\text { Not } \\
\text { agree }\end{array}$ & $\begin{array}{c}\text { Other } \\
\text { functional }\end{array}$ \\
\hline & $\begin{array}{l}\text { Mashi, Mashi not } \\
\text { forgetting }\end{array}$ & & & & & & & \\
\hline 19. & $\begin{array}{l}\text { Mashi, by coach's } \\
\text { instructions at } \\
\text { the club? }\end{array}$ & $\begin{array}{c}\text { Followin } \\
\text { g coach's } \\
\text { instructio } \\
\text { ns }\end{array}$ & & & & & & \\
\hline 20. & $\begin{array}{l}\text { Mashi, I'm going } \\
\text { to deal with you }\end{array}$ & Threat & & & & & & \\
\hline 21. & $\begin{array}{l}\text { Mashi and I'm not } \\
\text { Seeing anything in } \\
\text { front of me }\end{array}$ & Anger & & & & & & \\
\hline 22. & $\begin{array}{c}\text { I Put your dinner } \\
\text { in the oven, } \\
\text { Mashi? }\end{array}$ & $\begin{array}{l}\text { Confirmat } \\
\quad \text { ion }\end{array}$ & & & & & & \\
\hline 23. & $\begin{array}{l}\text { Talk is Mashi? } \\
\text { Talk is Mashi }\end{array}$ & $\begin{array}{l}\text { Confirm } \\
\text { the } \\
\text { correctnes } \\
\text { s of } \\
\text { speech }\end{array}$ & & & & & & \\
\hline 24. & $\begin{array}{l}\text { How fast you } \\
\text { were Mashi? }\end{array}$ & $\begin{array}{c}\text { The } \\
\text { Movement }\end{array}$ & & & & & & \\
\hline 25. & $\begin{array}{l}\text { This Guy is Mashi } \\
\text { straight ahead. }\end{array}$ & $\begin{array}{c}\text { The } \\
\text { behavior }\end{array}$ & & & & & & \\
\hline 26. & $\begin{array}{c}\text { He is Mashi on } \\
\text { the law very } \\
\text { carefully }\end{array}$ & $\begin{array}{l}\text { Commitm } \\
\text { ent }\end{array}$ & & & & & & \\
\hline 27. & $\begin{array}{l}\text { Luck is Mashi } \\
\text { with us very good }\end{array}$ & $\begin{array}{l}\text { Pleasure } \\
\text { and } \\
\text { optimism }\end{array}$ & & & & & & \\
\hline 28. & $\begin{array}{l}\text { The Road is } \\
\text { Mashi with us }\end{array}$ & $\begin{array}{c}\text { Straightne } \\
\text { ss }\end{array}$ & & & & & & \\
\hline
\end{tabular}

